\title{
拔 萃
}

\section{6. 高溫度測定用語の定義}

\section{Definitions of Pyrometric Terms.}

By Association of Scientific Apparatus Makers

J. Opt. Soc. Amer., 14, 4, April, 1927, pp. 346-347.

Industrial Group of the Association of Scientific Apparatus Makers から提出せられた次の高溫度測 定用語の定義を一般に使ふ樣に獎める。

妶に揭げられてある定義は皆 Bureau of Standards その他の大家の廣い討議の後はじめて決定せ られたものであつて、高溫度测定關係方面の用語に精通して居る人くの代表者の思想を採用した ஆのである。

定義

1. 寒暖計 (Thermometer) ; 溫度を測る裝置。

2. 高溫度計 (Pyrometer)；高溫を測る裝置。乙の語は、主として赤熱 (凡そ $500^{\circ} \mathrm{C}$ ) 以上の 溫度を測るるのに用ひられる。

3. 抵抗寒暖計 (Resistance Thermometer)；それの或る一部分の電氣抵抗が溫度に依て變る事を 利用して溫度を示す寒暖計。高溫度 $\left(500^{\circ} \mathrm{C}\right.$ 以上) 几用ひられる場合には、それは高溫度 計であつて、抵抗高溫度計 (Resistance Pyrometer)：と呼んだ方がよい。

4. 輻射高溫度計 (Radiation Pyrometer)：高溫度の物體が輻射する熱が溫度に依て變る事を利 用して溫度を示す高溫度計。輻射せられる熱の出來るだけ全體を使用する。通常熱電對を 以て溫度を測る。

5. 光度高溫度計 (Optical Pyrometer) : 高溫度の物體が放つ兆の强さが溫度に依て變る事を利 用して溫度を示す高溫度計。出來るだけ單一の色(波長)の光を用ひる。

6. 熱電對 (Thermo-couple)：二つつ接續點が違つれ溫度にある時、熱起電力を生する樣に綪び つけられた導體の一對、てれは違つた物質の導體をそれの一方の端で永久的に結びつけた ものであつて、他の端は起電力を測る器具に結びつけるために自由にしてある。

7. 熱起電力高溫度計 (Thermo-electric Pyrometer) : 熱電對の起電力が溫度に依て變る事を利用 して溫度を示す高溫度計、通常熱電對、ミリヴオルトメートル（或は起電力を測る他の器 具)、及び導線から成り立つて居る。測定器具は次の樣に分類する事が出來る。

\section{ミリヴオルトメートル \\ ポテンショメートル \\ てれ等の結合或は變形}

8. 高溫接合點 (Hot Junction)：熱電對の接合點の中溫度の高い方。

9. 低溫接合點 (Cold Junction) : 熱電對の接合點の中、高溫接合點よりも溫度の低い方。 との溫度は通常基準溫度である。 
10. 延長導線 (Extension Leads)：熱電對に結び付けられた時には、䡠際上の低溫接合點が導線 の他の端に移つて行く樣な物質で作られた一對の導線、屢補正導線とる呼ばれる。

11. 精密度 (Accuracy)：高溫度計の精密度を指定するのに、最大誤差を全目盛りの百分比とし. て表にしてもよいし、メは最大の溫度で指定してもよい。

12. 感度 (Sensitivity)：高溫度計の感度とは測定せらるべき溫度の小變化に對する感じ易さで ある、特别に高溫度計の讀みに $1 \mathrm{~mm}$ の戀化を生する溫度の最小變化と定義せられる。

(猪狩)

\section{7. 誘導電球に就て}

\section{The Induction Lamp, a new Source of Visible}

\section{and Ultra-Violet Radiation.}

By ted, E. Foulke.

A. I. E. E. Feb. 1927 .

電亚無を昜合の放電は最初 Sir J. J. Thomson によりて、Wimshurst 機と蓄電器を用ひて行は れた。放電は替線と、二個の球狀端子の間に於て行はれた。この場合の結線は第一圖の如くであ る。其後、ての賽驗は種くの人くによりて行はれた。
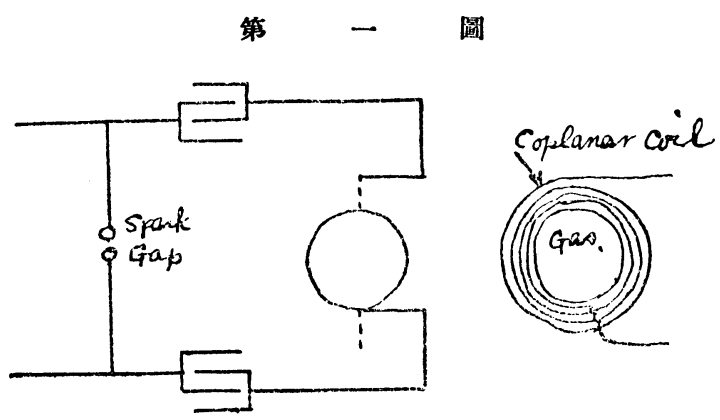

ての放電の現象は高周波變壓器に於 て、其の二次側に起るものと同一のも のである。而してそのアイオニゼーシ ヨン電位よりその誘導電壓が高くある 事が必要である。ての昜合に於て、其 の發光を爲す瓦斯に就て考ふる必要が ある。それは最初の電子の狀態、アイ オナイズさる〉行程、輻射の性能等で ある。各種の瓦斯に對して其の最小臨 界電壓は次の如きものである。

最小臨界 電壓

$\begin{array}{lr}\text { ケシューム } & 3.8 \\ \text { ソデューム } & 5.1 \\ \text { 水 銀 } & 10.4 \\ \text { アルニン } & 15.5 \\ \text { 窒 素 } & 16.3 \\ \text { ヘリューム } & 24.5\end{array}$

瓦斯體よりの輻射は白熱輻射體と異なり、不連䋶である。原子による輻射は單巴である。てれ は或る波長のものを創らさる䉆めである。

靜止狀態に對しては Bohr の理論より、式を立てる事が出來る。最も簡單なる水素の如をもの 
て對しては

$$
\begin{aligned}
& 2 \pi \times(\text { 觕モーメンタム })=n h . \\
& \mathrm{W}_{\mathrm{n}}=\frac{2 \pi^{2} m e^{4}}{l^{2}} \frac{1}{n^{2}}
\end{aligned}
$$

$\mathrm{W}_{\mathrm{n}}$ =靜止狀態 $n$ に於けるェネルギー

$n$ 假定したる Integral Value 1. 2.3 etc.

$e=$ 電子の電荷

$m$ =電子の質量

$h=$ Planck $の$ 定數

今 $\mathrm{W}_{\mathrm{a}}$ を晋通狀態のエネルギー、 $\mathrm{W}_{\mathrm{e}}$ を高位の狀態のエネルギーとすればての間に必要なるエ ネルギーは

$$
\Delta \mathrm{E}=\left(\mathrm{W}_{\mathrm{a}}-\mathrm{W}_{\mathrm{e}}\right)
$$

電子がての高位のェネルギーにある時。乙れは不安定のものであるから直ちに、舊位のるのに 復する。ての時に單色輻射を第すのである。ての場合の輻射の周波數等は次の如き式によりて示 さるるものである。

$$
\Delta \mathrm{E}=\left(\mathrm{W}_{\mathrm{e}}-\mathrm{W}_{\mathrm{a}}\right)=h v
$$

$v=$ 輻射の周波數

ての時間は約、 $10^{-8}$ 秒である。

第二 㬝

PLIOTRoN CIRCuIT.

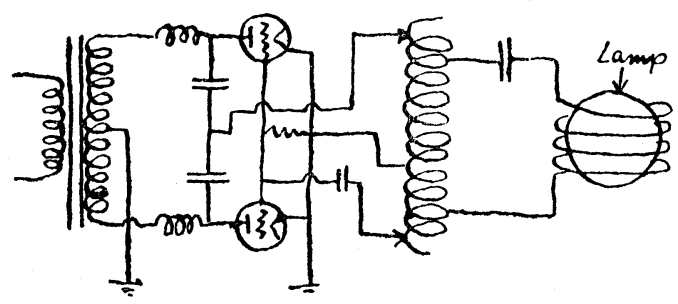

SPARK GAP CIROUIT.

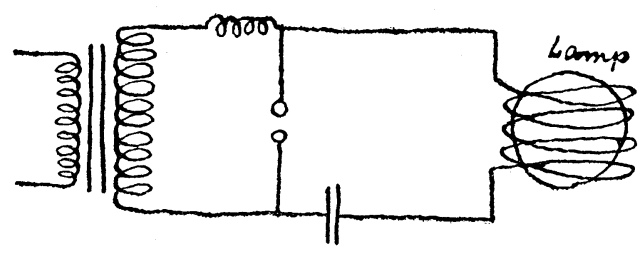

或る容器中に少量の瓦斯を入れ電磁 昜中に入れる時は正イオンは一方の方 向に動き、電子は他の方向に移り、電 流が容器中を流れる。

ての電流は衝突に依る、アイオニゼ ーションによりて增加する。

誘導電球を質驗する方法は大體二種 ある。其つ方法は 3000 ヴオルト。 15000 ヴオルトの變壓器と、0.001 乃 至 0.05 マイクロフアラッドの蓄電器 數個と放電間腺及びへリカルの路磁コ イルである。

他の方法は交流又は直流の數個のプ ライオトロン、蓄電器、镂磁ヘリカルコ イル等である。是等の各々は第二圖に 示すが如くにするのである。

$3.8 \mathrm{~cm}$ 直徑の水銀、アルゴンの誘 竔電球に使用したる各種の器具の大ん さを示すと次の如くである。
ヘリカルコイル

蓄電器

放電間腺
銅 7 㗭線、牛徑 $4 \mathrm{~cm}$ 間陌 $1.0 \mathrm{~cm}$

$$
0.005 \text { マイクロフアラッド }
$$

4. G, E. navy type units S. E, 
チョーク、コイル

變壓器
30. ミリヘンリー

5500 ヴオルト(二次)。高レアクタンス型

カロリメーター

カロリメーターは第三圖に示したるが如きもので內面が黑色に塗られたる箱である。內部の空 氣は一定の壓力の下に、電球の周圍を迴つて、循環せられ且つ又光度計の䉆に少なる空を有する ものである。內部の溫度は普通の寒暖計によりて測定される。溫度と時間との關係は光の如を筫 驗式によつて示さる。

$$
t=\mathrm{C} \mathrm{e}^{\frac{\mathrm{T}}{\mathrm{KW}}}
$$

$$
\begin{aligned}
& t=\text { 時 間 } \\
& \mathrm{T}=\text { 溫 度 } \\
& \mathrm{W}=\text { 入カ(ワット) } \\
& \mathrm{C}, \mathrm{K}=\text { 定 數 } \\
& \text { 上式よりして、 }
\end{aligned}
$$

$$
\mathrm{W}=\frac{\log _{10} e}{\mathrm{~K}} \cdot \frac{\Delta \mathrm{T}}{\Delta \log _{10} t}=\mathrm{K} . \mathrm{S}
$$

光度測定

光度測定はカロリメーターと同時に行つた。其の水平燭光を測定する爲に、Macbeth のイルミ ノメーター及び Sharp-miller の光度計を使用した。

\section{電球の構造}

電球は一般には球形で其の目的によりて、柔硝子、硬硝子、パイレックス、透明石英等が使用 される。其の貪空は 1 ミクロンの程度である。球は出來る丈け高溫度に加熱する。次に發光すべ き瓦斯等を球中に入れる。水銀の場合に球中に水銀を入れたる爲に加熱して、其の中の水蒸氣其 他の瓦斯を除き、次に買空ポンプを運轉しつつ高度の誘導放電を行ひ、然る後に封じるのである。 ての時の內部の酮力は 1 ミクロン以下なる事を要するのである。

晋通の室內溫度に於ては純粹つ水銀は誘導故電は起さず溫度の上昇するに從つて放電を起すの である。而して、水銀の場合にはメメラルド緣のグローを起すのである。溫度に對する燭光を示 すと第四圖の如くになる。

$$
\text { 第 } 三 \text { 圆 }
$$

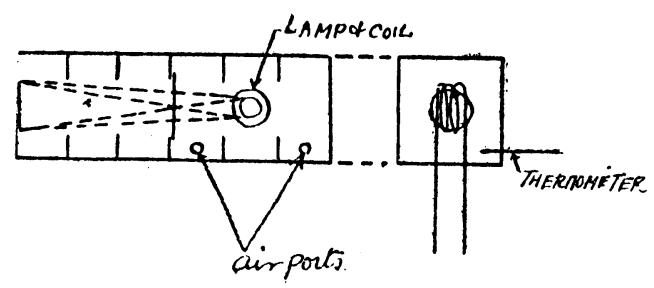

第 四

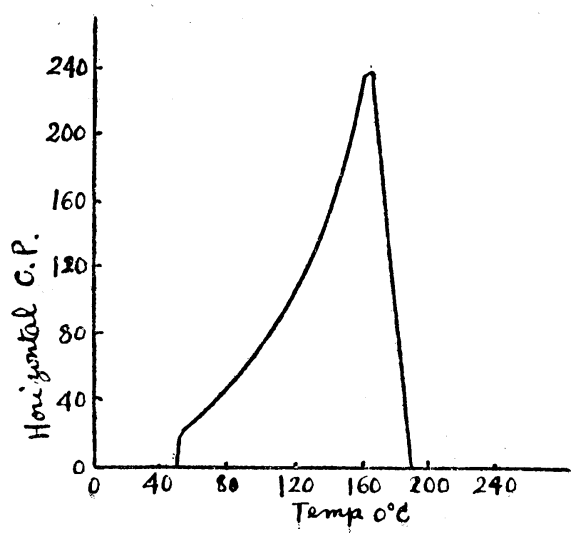


純粹の水銀球に對しては其の燭光は次の如き式で示される。

$$
\mathrm{B}=\mathrm{C} r \omega^{2}
$$

$\mathrm{B}=$ 水平燭光

$r=$ 球の半徑

$\omega=$ 入力(ワット)

$\mathrm{C}=0.77 \times 10^{-3}$

水銀誘導電球は、其の放電が生ずる迄、外部より熱する必要がある。又其のワット入力も、充 分の蒸氣埾力を保持する以上のものが必要である。其後に、水銀誘導電球に種々の瓦斯體を混ず る事が研究された。終に稀有瓦斯を混するる時は加熱せずに自己始動を第すものが出來た。一般に アルゴンがての目的に使用されるのである。是等の瓦斯體を水銀に混ずる事の利益は、第一に自 己放電を爲す事、义其のルミナスインテンシテーを增加せしむる事等である。乙の光度を增す事 はある極限があるのである。稀有瓦斯を封入したもののスペクトラムを驗べるる結果是等の瓦斯 によるものは球が泠き場合には現れ溫度が上昇すると消失するものである。而してての加へらる る、稀有瓦斯の捱力は球の大いさによりて變化するものである。

$$
\begin{gathered}
p=5.7 r^{-\frac{1}{2}} \\
p=\text { 純粹のアルゴンの涯力 }(\mathrm{mm}) \\
r=\text { 容器の牛徑 }(\mathrm{cm})
\end{gathered}
$$

種々の勵磁周波に對して實驗したるに、50000 サイクルの場合には放電の起らぬ時はへリリッ クコイルに約 300 アムペア流れたが 20,000,000 サイクルの時は數十分の一アムペアであつれ。

本文に示したる筫驗は主に 1,000,000 乃至 3,000,000 サイクルの場合である。

ての型の電球は可視光線、近紫外線及び紫外線を多く含むスペクトラムを生ずる故に其の補助 裝置が重要視されざる所に使用さるるるのである。

即ち、可視光線より、有效なる、照明が得られ、近紫外線の部分を用ふる時は䉆真及び、螢光 效果を得る場合に使用される。紫外線の場合は、治療、殺菌、褪色、光化學變化の增蕉等に使用 されるのである。(門倉)

\section{8. 實驗室用水銀弧登の構造 \\ Constraction of Mercury Arc Lamps For Laboratory Use.}

Cy D. S. Ainslie

J. Opt. Soc. Amer., 14, 4, April, 1927, pp. 354-355.

設備の豐かで疗い實驗室でる水銀弧燈を使ひ得る樣に出來るだけ簡單なるのを設計したるので あつて、長さ約 $20 \mathrm{~cm}$, スペクトルの賽驗に適する樣に弧を沿遖几使用する。

全體の形は圖に示す樣なものであつて、內徑 $1.6 \mathrm{~cm}$, 外徑約 $1.9 \mathrm{~cm}$ のパイレックス硝子で出 


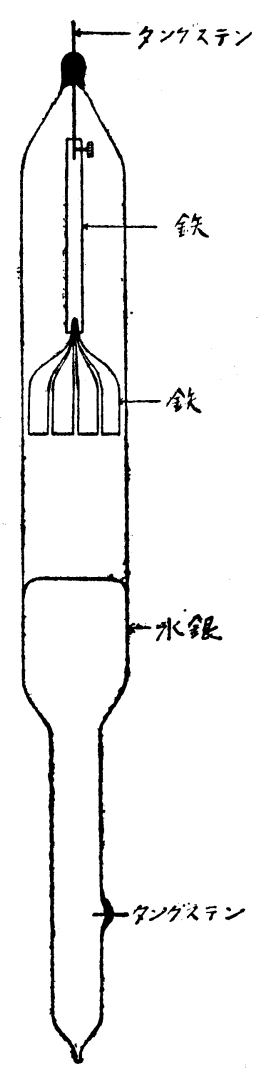

來て居る。陽極には古い Cooper Hewitt 燈から取つ た溥い鐵を使つた。

排氣して水銀をつめるために、圖で下の端を他の 硝子管に水平の位置につなき、その硝子管に水銀溜 を借へて置く、最初洗はなくてはならないのだが、 洗ふには稀硝酸、蒝溜水、純アルコールの順で 洗s。

賽驗室で使ふには、適當の抵抗を直列に入れて 110 ヴオルトの直流回路につなぐ、管の側面に附い て居る端子を下向きにして水平の位置に置いて始め 回路が閉ぢて居る樣にして後鉛直の位置に迴轉し得 る樣にスタンドに取り附ける。兩端子間の電厴は 16 乃至 20 ヴオルトで電流は凡そ3 アムペアであ る。薄い銅の鯺（譯者註：形狀不明）を水銀の上に 附け加へると電流を5アムペアに增す事が出來、從 つてスペクトルの赤及び赤外線を增す事が出來る。

（猪狩）

\section{9. 白熱電燈檢定裝置}

\section{A Machine for Rating Incandescent Lamps.}

By C. G. Eden and N. R. Campbell.

J. Scient. Inst., IV, 2, Nov., 1926, pp. 38-42

光電池を使用して電球が指定せられた能率を與へる電筭を定める裝置に就て述べてあるのであ るが、その目的は前に述べた精密な方法 (J. Scient. Inst. 2, 1925, 177 及び 3, 1925, 2) に於て精 密さは犧牲として仕事を早くやりたいといふ點にある。所要の電壓がある範圍內にあるからどう かといふ事を知るには極めて精確である事を要しない。電壓で $2 \%$ 精密さを得るものとして論 を進める。

仕事の早さは次の三點で制限せられる。

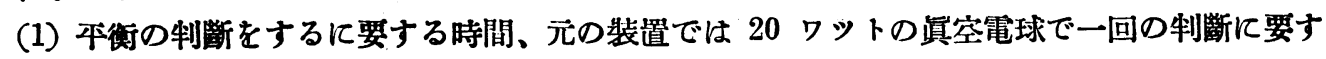
る時間は 2 秒、或る範圍にあるかどらかを定める二回の制斷には 4 秒であつた。るつと光度の高 レもの、能率の高レものでは幾らか短かくなるだらう。

(2) 電球を光度計に入れるに要する時間、元の裝置では 30 秒であつた。

(3) 電球が定まつた狀態になるに要する時間、2\%の精密さで滿足するならば、若しも電球を 
豫め若干點火して置く時は、てれに要する時間は (1)の程度である。然し電球を初めて點火する ならば凡そ 3 分を要する。それ故に電球をその製作後直ちに試驗する場合には、所要時間は (3), (2), (1)の順となり、エーヂした後に試驗すれば（2）が最長となる。

回轉の中心から輻射狀に出て居るホールダーに電球6個を取り付け、ハンドルで各の電球を順々 に光度测定裝置に持ち來る。Iの位置では點火せず、こ」で 6 電球の洼し挨へをする。II, III, IV, V. では電球は略一定の電厴で點火せられ、その間に一定の状態になる。VI の位置では涀定用の 回路に來る。てれ等の取扱ひはコンミューテーターで行はれる。

VI の位置で電球は下から上つて來る筒の中に入り上から蓝をされる。筒の底には二つの光電 池が入つて居るハウジングがあり、てれは趈轉して居る。

光は直接光電池に當らない樣にスクリーンがある。若しも電球が同じ型のものであり、同じ樣 に筒の中に入つて居るならば、ての筒は球の代用をする。

光電池の使ひ方は前に述べたと同樣であつて、ナトリウム・セルとルビヂウム・セルとがスぺ クトルル對して感度が違ふ事を利用して、測られる光の色がある標準の光と同じ色になる電壓を 讀む樣な原理になつて居る。

ての時に用ひたェレクトロ・メートルは Cambridge Instrument 會㖶製の Lindeman 型であつて、 早く讀む事が出來、又零位が安定である。

裝置を更正するには、それの格定電壓の知れて居る、試驗燈と同一ワット、同一形狀の䌦保の 標準燈を用ひる。

早さと精泌I との試驗を行つたが、精泌さは電球自身の constancy と電壓計の目盛りとに制限 される。商品の真空電球ではこの極限は殆ど一定で、0.1\% である。瓦斯入電球では電球の働程 の相違から $0.5 \%$ 位不定になる。 40 ワットの真空電球一個を定格するのに 15 秒を姴する。同 種の電球 50 個を數回の測定した時の mean root square error が $0.13 \%$ であつた。文早さよりも 精密さに重きを置いた光度計でも同じ位の誤差があつた。

光度計を單に格定電壓が指定の值から $2 \%$ の誤差の範圍內にある事を定めるために讀みを二つ とるのに凡そ 3 秒かかる、若し電球を出し入れする事を外の人がやれば一時間に 300-350 個の 早さで上の範圍內に定格する事が出來るであら5。更に色々の動作が自働的に行はれる樣にすれ ば一人でのてれだけの早さを得る事が出來るかも知れない。

普通の視覺光度計と比較するに、壽命試驗に使ふ光度計で二人の觀測者で一定の電壓に於ける 電流とルーメンとを讀んで一時間に 200個を定格する事が出來る。同じ種類の電球で觀测をやつ た時の mean error は一定の電埾に於ける能率で $0.9 \%$ 即ち一定の能率に於ける電壓で $0.4 \%$ で 光電池に依るものより遥て劣る。(猪狩)

\section{0. 光電池の彈動性質}

\section{Ballistic Characteristics of the Photo electric Cell.}

By. F. F. Null.

Opt. Soc. of Amer. January, 1927. 


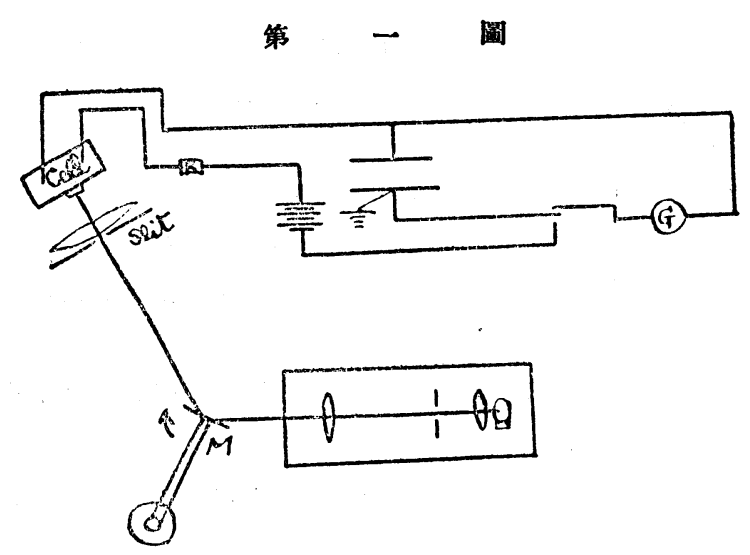

(a) 蓄電器充電方法

光電池に種々の距離より光を當 て其の生する電氣量を測定する目 的に蓄電器を使用したるのであ る。これは或る一定の間光電池に 光を當て、その電流にて蓄電器を 充電し、後にてれを彈動检流計に よつて、湘定するものである。光 電池之蓄電器と直列にて 67 ヴオ ルトの電池を結ぶ。露出は回轉す る光線を使用し、光電池の外にス リットを置レて行つた。光源には自熱電球を使用し光線を回轉せしむる䉆には第一圖に示す如 く、回轉鏡を使用した。回轉鏡は蓄昔器の原動機を使用し、0.016 乃至 1.1 迴轉每秒の速度にて 回轉されている。

光電池の前にはレンズが置かれ其の前にスリットが置かれてある。

スリットの間腺は任意に變化出來るものである。

蓄電池はスリットの前に光線が來た時に光電池と直列に結ばれ其の光線がスリットの前を過ざ た後に直ちに檢流計を通じて放電させるのである。

(b) 單一胍動增輻裝置

ての裝置は回轉光線を光電池に當て、それによつて生じた電流を熱電子の燴輻裝置にて埢大 しててれを彈動檢流計にて測定するものである。光線を回轉せしむる裝置は（a）の場合と同一で ある。而して光電池による電流は第二圖の如き接縝によつて测定されるのである。ての場命には 丠電器は使用されず光電池の電流はグリッドリークに通じて流される。

ての場合に使用される垻輻器の設計 に對して重要なる點は直流のプレート 電流である。ての爲に Dl. C. と胍動プ レート電流とを分けて使用した。鉛電 池を使用する時は其の發泡によつて電 厴を變する故に乾電池をフイラメント 電源として、使用した。且つ又其の成 極作用を減少する爲に多くのものを並 列飞使用した。

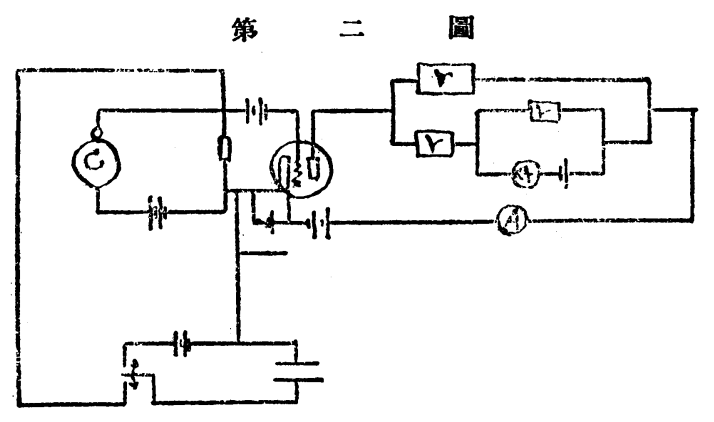

其の端子等は充分に絕線された。抵 抗としては油浴のマガニン線を使用した。

ての增輻器汢或る蓄電器を種々の電㻺にて无電してれを增輻裝置の回路を通じて、放電せしめ て其の性質を試驗した。又彈動檢流計も蓄電器の放電によりて更正された。

斯くして、光電池の彈動性質を試驗したのである。ての場合は炏ぎの如を定數を使用した。 スリットのウ二回動光線の巾 $=18.5 \mathrm{~mm}$ 鏡の中心より、スリット迄の距離 $=381 \mathrm{~mm}$ ての場合は光線のゆとスリットのウが等しい場合である故に、露出された時間は 


$$
\mathrm{T}=\frac{1.85 \times 60}{2 \times 381 \times 2} \cdot \frac{1}{(r \cdot p \cdot m)} \text { 秒 }
$$

第 三圆

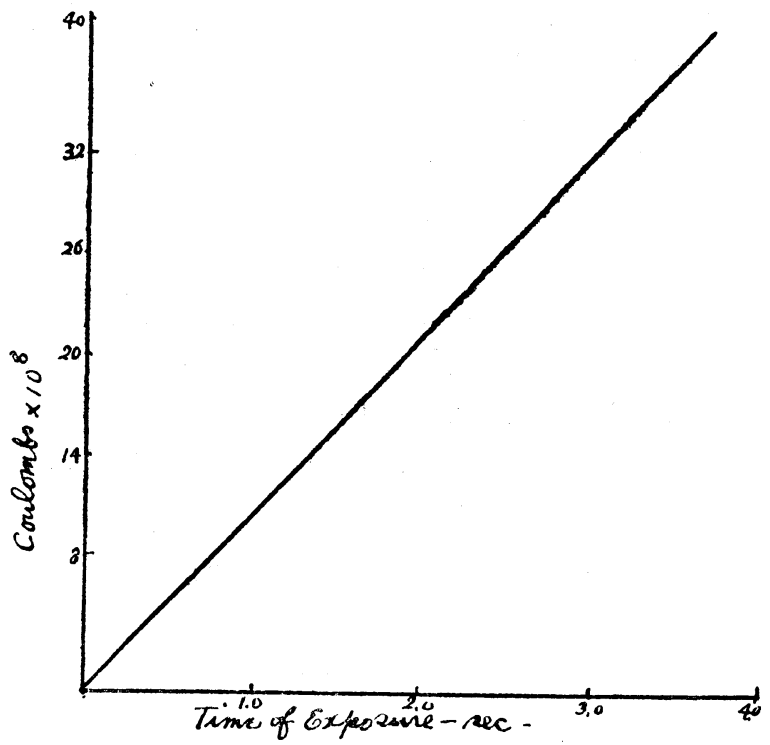

露出時間の長き場合には蓄電器 充電方法を用ひ露出時間小なる時 は熱電子增輻裝置を使用した。こ の結果露出時間に對して直線のも のとなつた。蓄電器は一マイクロ ファラドのものを使用したのであ る。光電池彈動性質は第三圖の如 くである。ての曲線は兩方法が重 なり合つたものであるが直線とな つた。

次に、光電池の露出を一定とな し其の光の强さを變化して測定し た。この光の强さを變する最も簡 單なる方法は二個のニコルプリズ ムを使用する事である。ての結果 は第四圖に示すが如くになつた。

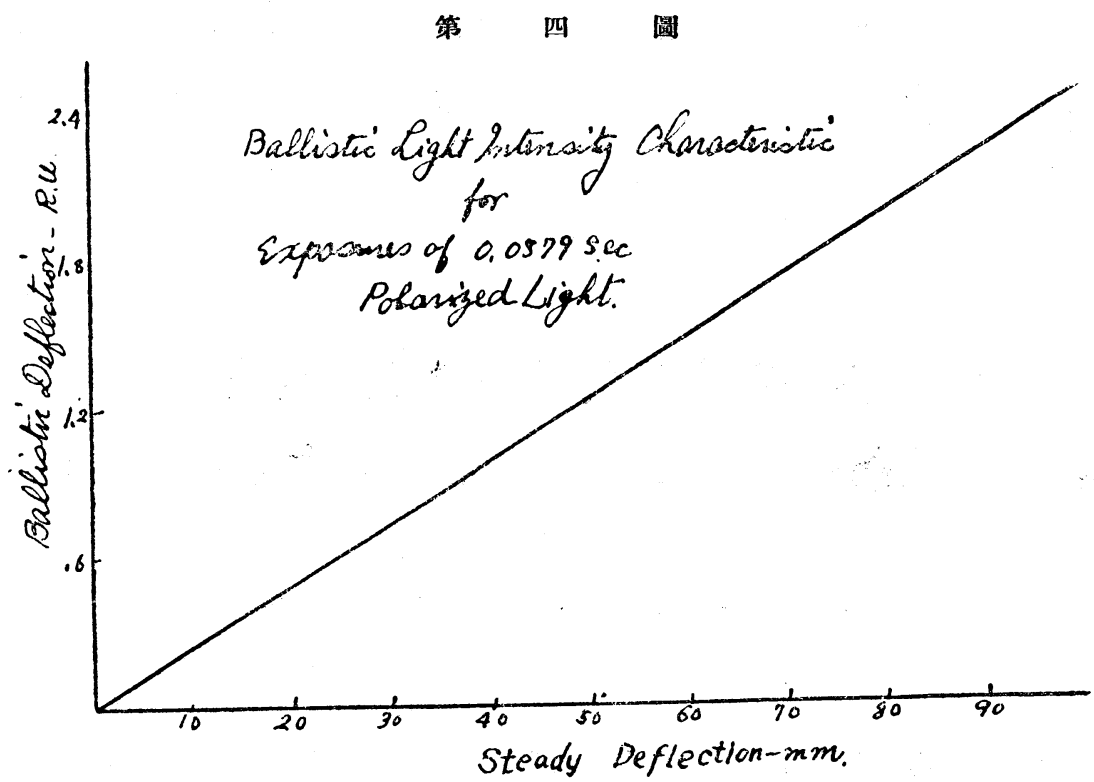

竄畺器のシャターの更正

上述したる實驗の結果或る定まつた時間に光電池によつて出される、電氣量は其の時間に受 けた光のエネルギーに正比例し、時間に對する光りの分布には關係せざる事を知つた。故に光電 池竄悬器のシャター其の他の光の遮断器を測定するに便である。この場合第五圖に示すが如 く、光線と光電池との間にシャターを入れればよとのである。これで其のシャターの開開度を變 
化せしめて測定すればよんのである。先づシャターの開閉時間を定め光電流による靜止振れを测 定してれを與へられたるシャターの彈動振れで除し、F (Coulombs per sec / mm) / G (Coulombs /mm) を乘する時は其の露出の間の光電池によりて出さるるエネルギーの比を得る事が出來る。ての數 の逆がシャターの時間を與へるものである。若しシャターの開閉に要する時間が其の開きたる

第五圆

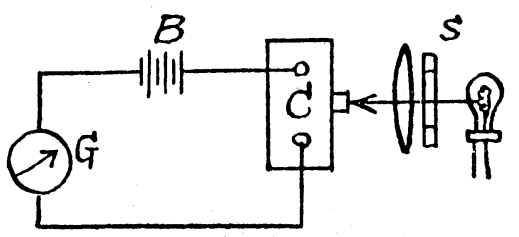

時間に對して小なる時は其の開閉時間に對しては能 率は $100 \%$ である。今開閉面積に對して小なる絞り を使用する時はその絞りを小さくする程その開閉能 率は 100 パーセントに近づくのである。一定の開閉 時間に對して、種くの絞りを使用する時は其の面積 て對する檢流計の振れの曲線を得る事が出來る。

實際の昜合に對しては其のシャターの㗢レている

間の全䱏のェネルギーが必要である故にての目的には光電池を使用するが便である。シャターの 製作會峒によりて行はれた寫真法によるシャターの時間測定法と、光電法による結果を示すと次 の如くである。

\begin{tabular}{|c|c|c|c|c|c|}
\hline \multirow{2}{*}{$\begin{array}{l}\text { シャター } \\
\text { の 記 號 }\end{array}$} & \multirow{2}{*}{ 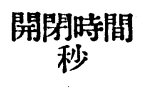 } & \multirow{2}{*}{$\begin{array}{c}\text { 彈動の振れ } \\
\text { mm }\end{array}$} & \multirow{2}{*}{$\underset{\text { mm }}{\text { 靜止の振れ }}$} & \multicolumn{2}{|c|}{ 眞の開閉時間 } \\
\hline & & & & 光電池方法 & 寫這方法 \\
\hline $\begin{array}{c}1 \\
10\end{array}$ & 0.1 & 19.0 & 305.6 & 0.109 & \\
\hline$\frac{1}{25}$ & 0.04 & 7.28 & 305.6 & 0.0416 & 0.410 \\
\hline$\frac{1}{50}$ & 0.02 & 3.32 & 305.6 & 0.0190 & 0.019 \\
\hline$\frac{1}{100}$ & 0.01 & 1.46 & 305.6 & 0.00837 & 0.009 \\
\hline$\frac{1}{150}$ & 0.0066 & 1.46 & 305.6 & 0.00837 & $\begin{array}{c}0 \cdot 009 \\
\text { (門倉) }\end{array}$ \\
\hline
\end{tabular}

\title{
21. 擴散硝子製照明器具の輝度
}

\section{Surface Brightness of Diffusing Classware for Illumination.}

By. Grieveson.

\author{
Illumination Research, Technical Paper No.4, Department of
}

Scientific and Industrial Research. 1926

本報告は英國國立物理筫驗所で空內照明用の搌散ボール十八個につレてその辉度を測定した結 果の報告である。各ボールにはその製造者が推獎してなる大さの瓦斯入電球をとりつけ、被照面 の離れてねる照度計で測定した。この被照面の反射率 $\rho$ を豫め他の測定で求めておいて、ボール のある部分の輝度をはかるときは、乙の被照面の代りにボールの面の蛼度を测定する。照度計は 呎燭で較正してあるから、その值に $\rho / 144 \pi$ を乘ずれば每本方时の燭光數で輝度が求められる。勿 論照度計用の被照面は完全擴散反射をするものと考へてのてとである。

ボールの形狀。 
測定に用ひたボールは種々の擴散型のものの代表的のもので、その大さと形とから三つに大别 する。第 1 群は 5 個 (第 1.2.15. 16. 17) で、形は牛球、緣の處で直徑約 16 时である。第 2 群 は6 個(第 3. 4. 10.11. 12.13) で形は牛球、緗の直徑は 12 时である。牛球とはやや形が牛球 とは少しちがふけれども直徑が同じであるから第 6 及 7 のボールもこの群に入れる。第 3 群は形 も大さも區々で殆んど全圍器具である。(第 5. 8.9.14. 18)

材料の點から云ふと次の三群になる。（1）白丈ばポットオパール（pot opal）、( 2 ）フラッシュ ドメはケースドオバール (Flashed or cased opal)、(3) 牛透明アラバスター (Translucent alabaster)

第 1. 2. 9. 11.18 の個は第 1 群、第 3. 5. 6. 7. 10. 12. 13. 14. 15 の 倜は第 2 群、其 他第 4. 8. 16. 17 の 個は第 3 群に屬する。

本報告には寫買で外觀を示してなる。寸法やそれに用ひる瓦斯入電球の大さを第一表に示す。

\begin{tabular}{|c|c|c|c|c|c|}
\hline 番號 & $\begin{array}{l}\text { ボールの } \\
\text { 最大直徑 }\end{array}$ & 他 の 寸 法 & ガラスの種 類 & 形 及 他 の 特 長 & 電球の大さ \\
\hline 1 & 16インチ & & ポツトオパール….............. & 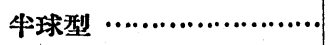 & 300 ワット \\
\hline 2 & 16 & & " $\quad$ " $\quad \ldots . . . . . . .$. & 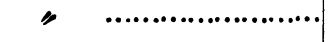 & 300 \\
\hline 3 & 12 & & ケーストオパー ル…..... & " (淡綠色) ……....... & 200 \\
\hline 4 & 12 & & 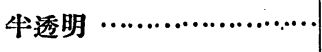 & " (ひだ付) ….......... & 200 \\
\hline 5 & 12 & $\begin{array}{l}\text { 深さ } 6 \frac{1}{2}(\text { インチ) } \\
\text { 緣 } 5 \frac{1}{2}=\end{array}$ & ケーストオパール…..... & 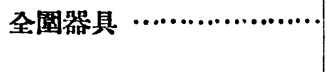 & 100 \\
\hline 6 & 12 & $\begin{array}{l}\text { 深さ5 } \frac{1}{2}= \\
\text { 緣 } 10\end{array}$ & " " & 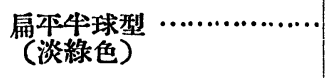 & 200 \\
\hline 7 & 12 & 深さ4 $\frac{1}{2}$ & 艷消 オパール…............. & 扁平牛球型 ……............... & 200 \\
\hline 8 & 10 & & 牛透明 $\ldots . . . \ldots \ldots \ldots \ldots \ldots \ldots$ & 球型(溝付) ……............... & 100 \\
\hline 9 & 10 & $\begin{array}{l}\text { 深さ } 8 \frac{1}{2}= \\
\text { 綘 } 6=\end{array}$ & ポットオバール…...... & 全图器具 …………… & 100 \\
\hline 10 & 12 & & ケーストオパール…....... & 牛球型 $\ldots . . . . . . . . . . . . . . . . . . .$. & 200 \\
\hline 11 & 12 & & ホワイトオパール…........ & $\quad$ (n........................... & 200 \\
\hline 12 & 12 & & ケーストオパール…..... & 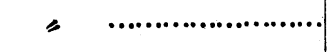 & 200 \\
\hline 13 & 12 & & $"$ & $\quad \quad$........................... & 200 \\
\hline 14 & 14 & $\begin{array}{l}\text { 樑さ } 8 \frac{1}{2}= \\
\text { 緣 } 4 \frac{1}{2}=\end{array}$ & " $\quad$,...... & 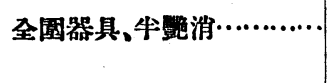 & 100 \\
\hline 15 & 16 & & $" \quad$ " $\quad \ldots . . . .$. & 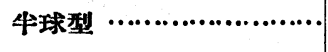 & 300 \\
\hline 16 & 16 & & 牛透明 $\cdots . . . . . . . . . . . . . . . . .$. & " (溝付) …............... & 300 \\
\hline 17 & 16 & & $" \quad \quad \ldots . . . . . . . . . . . . . . . . . . .$. & " (廣狄ひだ付) …... & 300 \\
\hline 18 & 12 & $\begin{array}{l}\text { 深さ9 } \\
\text { 維 } 6\end{array}$ & ホワイトオパール…........ & 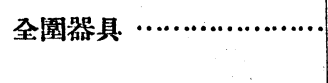 & 100 \\
\hline
\end{tabular}

試驗方法につんて。

試驗をするときには各ボールを天井から少しはなして吊り下げ、それぞれ適當な電球を入れる。 表で解かる樣にボールの大部分は牛球であるから、全圍器具をのぞいたものは全部、緣のやく下

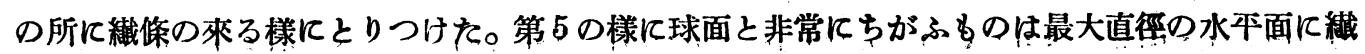




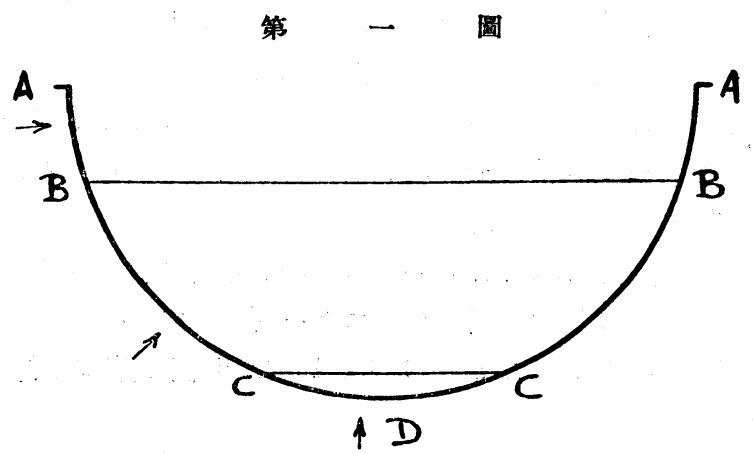

測定した部分

保をおく様にした。

ボールの種くの點で辉度を測定

したが、最も辉いた點が見える處 は特て注意した。硝子の表面上で 單位距離がかはつたための辉度の 變化を測定したが、晋通よりもそ の變化が大きい樣な處について測 定したのである。

讀みをとつた範圍はボールの形 によつて種くちがふが、大體から 云ふと次の三部である。

（I） A B の部分、緣から 2,3 时下までの部分

（2）ＢＣの部分、中心から $45^{\circ}$ の方向を中央とした部分

（3） C D の部分、中央部分

試驗結果、ての試驗の結果は第二表に示してある。本報告には圖でもあらはしてある。

第 = 表

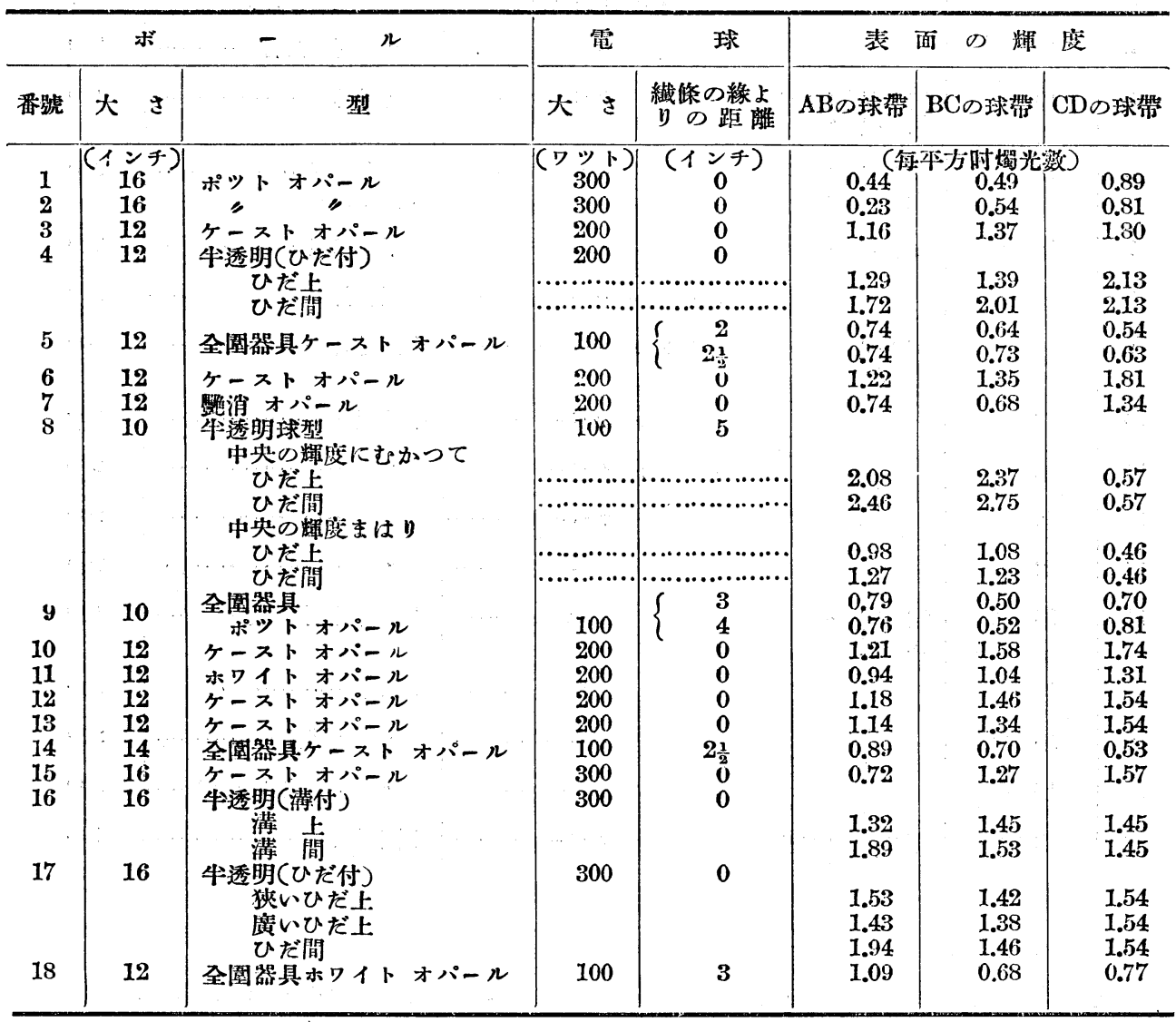

18 個の中 1 個第 8 だけは繊條が紅い系の樣に見えた。どの方向から見ても、㵶條のまはりに、 ボールの射影面積の 4 分の一が 3 分の一位の輝いた部分が出來る。それで二組の測定をした。一 

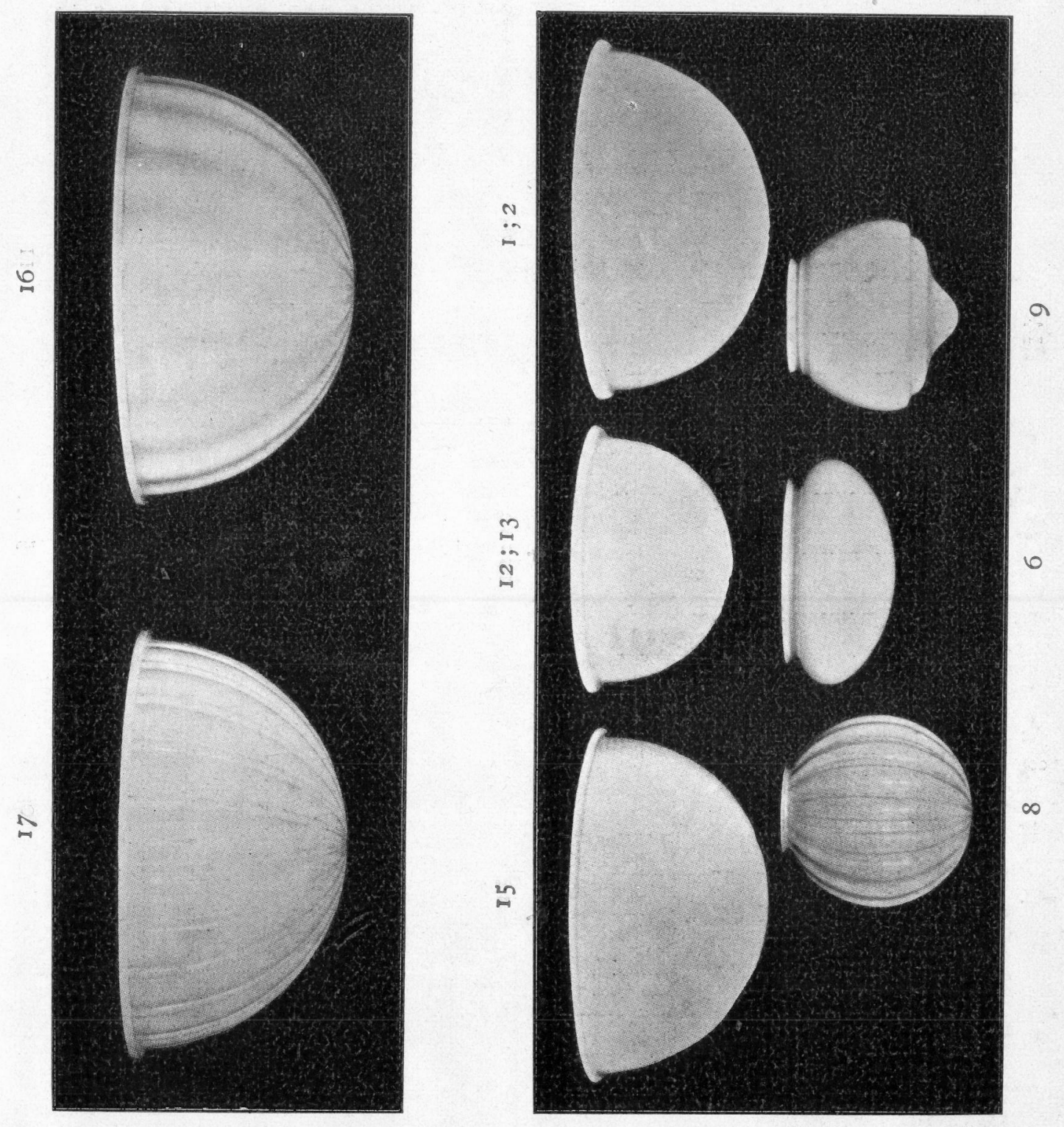

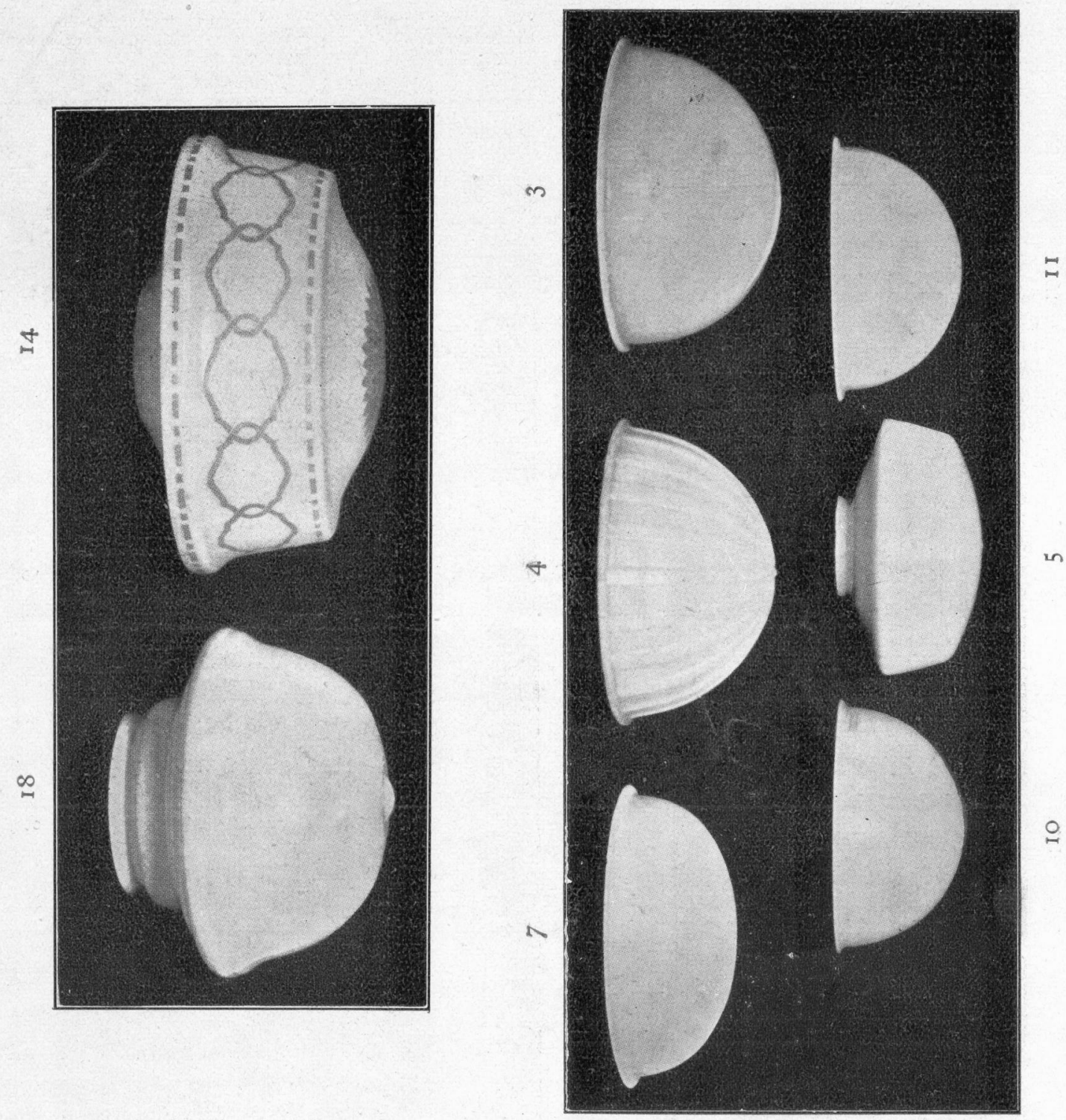
つは纎條の見える部分、他は見えないやう喑い部分である。

援散性の均一度につんての試驗の結果は試驗したるのは非常によい結果を示してるる。

大部分のものは垂直面中 1 时の距離のちがひによる辉度の變化は非常に少い。第三表に示した

4 倜のものだけが附近の本均值より $10 \%$ お注變化を示してなるのである。

\begin{tabular}{|c|c|c|}
\hline 番 諕 & ボール 大さと型 & 时 賞 \\
\hline 1 & 16インチ ポツトオパール & $23 \%$ \\
\hline 2 & $n \quad n$ & 31 \\
\hline 7 & 12インチ 蹬消 オパール & 33 \\
\hline 13 & 12インチケーストオパール & 17 \\
\hline
\end{tabular}

（山內）

\section{2. 鐵道用照明器のレンズ及び反射器}

\section{Lenses and Reflectors for Railroad Serrice.}

G. E. Rev. Feb. 1927.

鐵道事業に使用されている照明器は比較的舊式のものと最新式の二種がある。舊式のものは Fresnel レンズを用ひをもので他のものは Fresnel レンズを用ひたるものに比して、餘程其の構造 が複雜したものである。

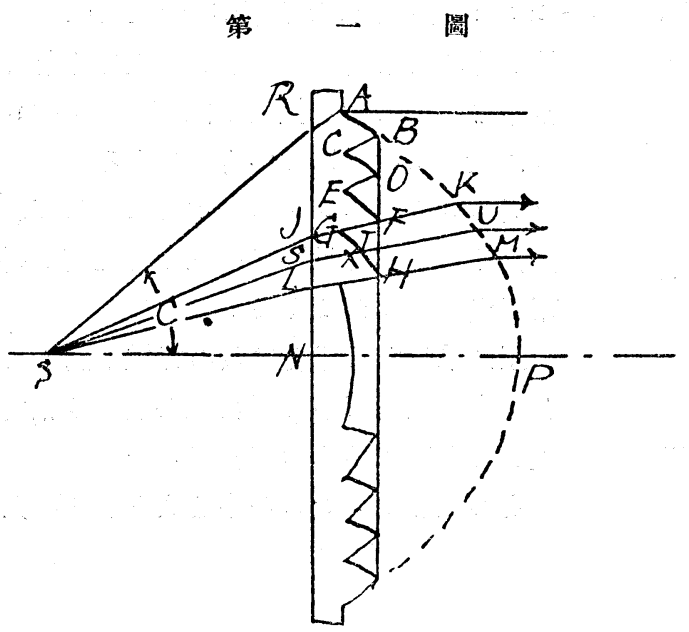

Fresnel レンズ

Fresnel レンズは Augustus Jean Fresnel によりて、發明されたものである。レン ズの集光力は其の厚味に關係するもので ある。大なる集光力を得るためには厚を レンズを必要とするのである。然しレン ズが厚くなると其の光の吸收も又大きく なるのである。其色を有すものに對し ては吸收が售大きくなり又其の價格も高 くなる。第一圖に於て、點線は PlaneConved レンズを示したもので S 凡光源 を置いた時に並行光線を得らるるもので ある。集光角度 $\mathrm{c}$ は大であり又其の中央 の厚味は可成り厚いものとなる。Fresnel は中央の厚味 N P を減ずる事を行つた

のである。第一圖に於て、A B P なる面は A B C D 一 W なる面に置き換へたのである。ての A B C D - W なる面が Fresnel レンズを第して居るのである。K M なる曲線は G H K並 行して居り $\mathrm{G}$ 李る面は $\mathrm{K}$ なる面に平行店事を要するのである。 
同樣に H 面は M 面に並行である。Fresnel レンズを賽用にする場合に、“Riser”が光線に對 して干涉せさる事及び全部を鑄物として製作し得る事である。商業的にてのレンズを取扱ふ場合 には其の面を磨くと云ふ事は不可能である故に銀物とされたものが直ちに使用する事が出來る必

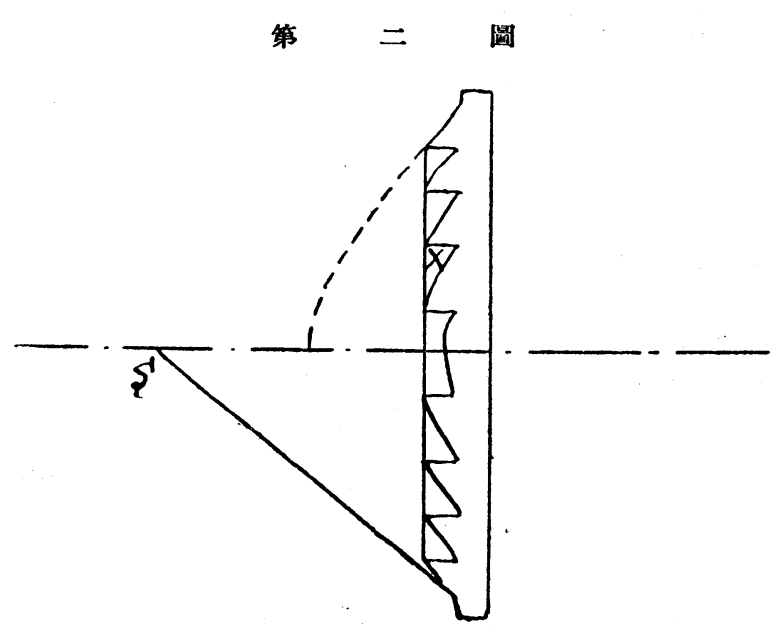

大體の大んさを示すと炏の如くになる。

\begin{tabular}{|c|c|}
\hline 直 徑 & 3.75 \\
\hline 厚味(最大) & 0.50 \\
\hline 同 (最少) & 0.25 \\
\hline 届 折 率 & 1.52 \\
\hline
\end{tabular}

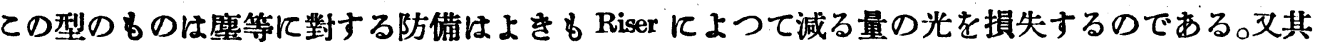
の届折が主に第一表面に於て、行はれるのが缺點である。

第三圖に示したるのは、外面る少しく球面をなし、Fresnel 段の數を減少したるものである。

斯くする時は Risers による損失を 36 乃至 30 バーセント減少せしむる事が出來るのである。 第三圆に於て、A B C の如き Risers より逃れる光の量が時に有用なる光の量より大きくなる事

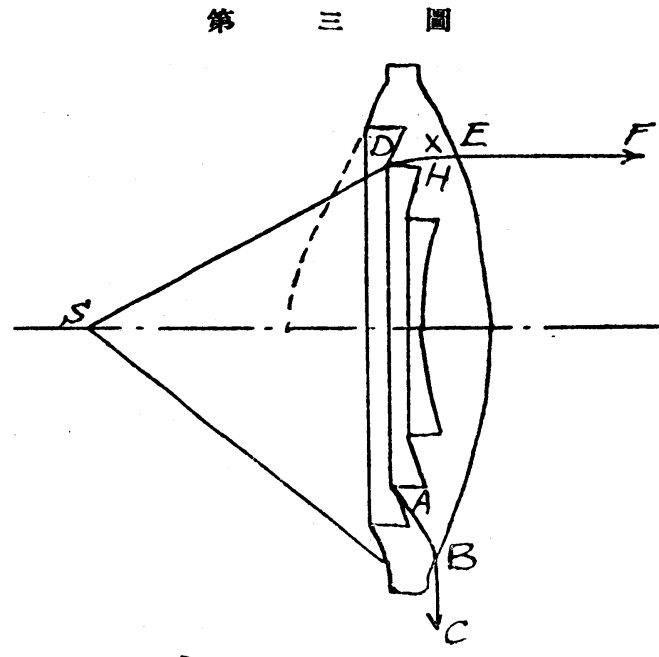
がある。斯の如き損失は內面 Fresnel レン ズに對しては避け難いるのである。 斯の如き型のレンズは電球に對して、最 大なる室を與人且つ叉一樣なる光芒を得る 事が出來るるのである。

圖に示したる易合は斯の光線が點である と假定した時であるが賽際の場合は相當の 大レさを有するものである。

その角度はレンズの中心より、10 乃至 20 度を含むものである、故に芒光も、又 10 乃至 20 度の角度にあるものである。 艺光中に於て一樣の光度を得んとするには レンズの總ての部分に於て一種の光の展開 が必要である。てれを得るには約光源が球 狀を爲す事が必要でする。 
今迄迅べた三栍のレンズに就き種々の點に對して表示する時は次の如くになるのである。

\begin{tabular}{|c|c|c|c|}
\hline & $\begin{array}{l}\text { 平面凸狀 } \\
\text { 第一圖 }\end{array}$ & $\begin{array}{l}\text { 凹狀平面 } \\
\text { 第 三 圖 }\end{array}$ & 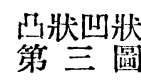 \\
\hline 光りの透過 & 1 & 3. & 2. \\
\hline 色の分數 & 1. & 3. & 2. \\
\hline 表 面 & 1. & 3. & 2. \\
\hline 電球に對する空間 & 2. & 3. & 1. \\
\hline 清＼cjkstart浮 & 3. & 2. & 1. \\
\hline 簡＼cjkstart單 & 3. & 2. & 1. \\
\hline 芒光の一樣 & 2. & 3. & 1. \\
\hline 全體に就ての順位. & 2. & 3. & 1. \\
\hline
\end{tabular}

鐵道ヤードに對する湓光照明

鐵道は 24 時間引き䋶いた作業をするものである。長年の經驗とは云へ、手持燈火にて、夜間 操車する事の出來るは不可思議である。

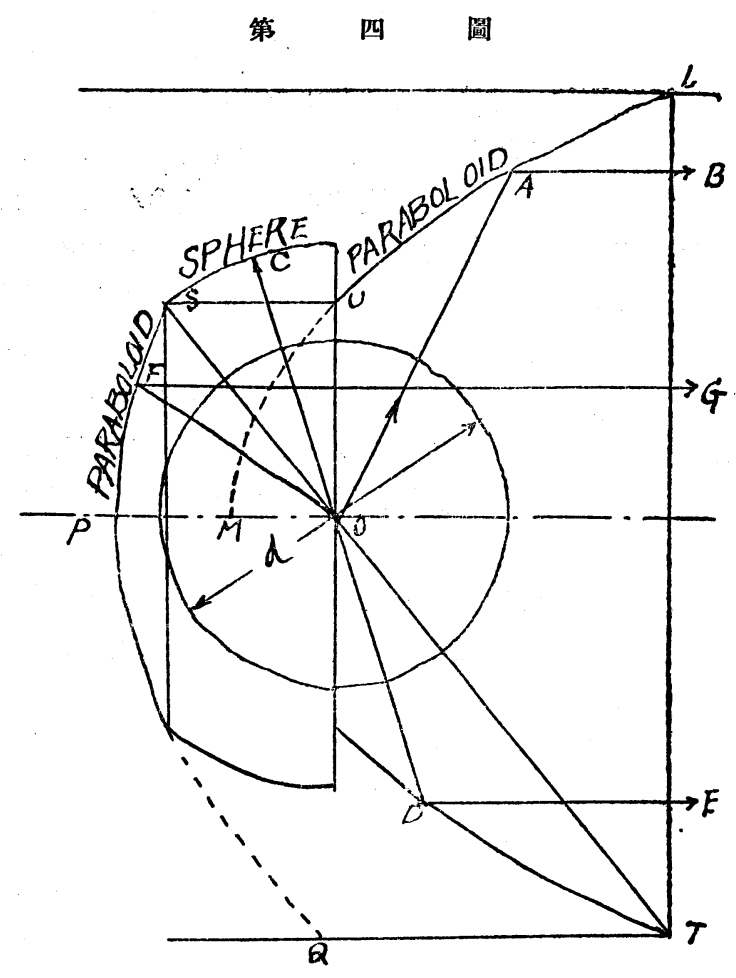

鐵道のヤードに對して一般照明が必 要なるのと考へられたのは極めて最近 の事である。

ての目的に使用される鰛光照明器は 各種あるが今其の一種に就いて考へ る。鐵道のヤードに對しては、其の艺 光が適當廣い角度を有する事が必要で ある。ヤードは一般に、廣大なる面積 のものである営に、一箇所より、照明 第し得るものでは無いのであるから是 等に對しても充分考ふる必要がある。 何れの種類の溢光照明器に對して ๖、二つの極限がある。即ち、第四圖 几於て、L T なる最大の直徑と電球の 直徑 d とである。圖に於て、P Q な るバラボラは其の反對面の端に或る極 限がある時に充分なる反射を爲す事が 出來る焦點距離 O P が必要である。 今バラボラ、M A L が電球に對する室 は無きも多くの光りを集むるが如くに 設計されたものとすれば電球て對する 室を作る䉆めに二つのバラボラを球にて、結び合せる時は適當なるのを作る事が出來る。圖に 於て、Oより、軸て對して垂線を作りパラボラ迴轉體とU U於て交らしめUより、軸て本行 線を引き、T O の延長と、S てて交らしむ。O は中心として球を作り又、S を通るパラボラ迴 轉體 P S を作ればよい。斯くして、二對式の反射器を作る事が出來るのである。ての昜合 OA. 及び O F なる光線はバラボラの面によつて、反射される。而して、O C の如きものは球面にて 反射されて、光源に反り、D 點によつて反射されて、並行光線を得るのである。斯の如き反射器 
の集光能率は 0.80 几達しての種の反射器に於て最大なるものである。(門倉)

\section{3. 街路照明の合調制御}

\section{Resonant Control for Street Lights.}

By. C. A. Boddie

The Electric Journal, Feb. 1927.

街路照明用の回路は三種ある。即ち變電所に、定電流調整機を設けたる直列式、定電埾の供給 を受け、ポール型定電流調整機を有する直列式、及び、定電厘の 並列式である。第一の式の ものの利點は變電所に於て、簡單に、制御し得る事である。ボール型のるのは遠方に離れたもの 叉は街道に沿つたものに使用さるるのである。ての場合は他の回路より繼電器、バイロット線、 時計、又は手動によつて制御されるのである。並列式は、下町等の場合に使用される。ての場合 の制御は杜の下に設けられた開閉器を手で働かすか、又は時計式の開閉器を使用するか又はバイ ロット線等を使用して行ふのである。最近には彼の二者が非常な勢で發達しつつあるのである。

定電壓式に於て直接文は定電流變娾器を使用し、其の回路に他の周波數のものを入れて合調せ しめ回路を制御する方法が發達した。この方法は簡單で且つ、激價に行ふ事が出來、一對の合調 繼電器を回路に入れて使用するのでをる。ての合調繼電器は其の回路の使用周波數に對して働か ず、660 サイクルが入れられた時に、繼電器は働ひて其の開閉器を閉ぢるのである。而して 440 サイクルが來た場合に他の合調繼電器が働ひて、開閉器を開き街路電燈を消す。この方法は今使 用されている一般の配電方法に對して、便なるものであり、特に地下ケーブルのるのに對して適 しているのである。ての合調整御を行ふ事に對して考へる點は高周波發生裝置と、合調繼電器と である。

合調繼電器を働かす䉆の高周波發生裝置は二つの速度即ち 1200 及び 1800 回轉の誘導電動機 によつて回轉される單相交流機にて行はれるのである。この發電機は其の各々の回轉數によつて 440 サイクル及び 660 サイクルの交流を起するのである。

ての發電機は一組又は數個の饋電線に結ばれその各くは、インダクタンスコイル及び蓄電器を 有するものである。乙の蓄電器は力率補正用几使用される油入のるのである。インダクタンスコ イルは然心型のもので銅線を減少する䉆て撜り線を使用している。

而して、合調回路と發電機の間には適當なる變篹器が入れてある。若し、饋電線リアクター。 又は餚電線調整器の瞶電側に合調回路を入れるなれば、變電所裝置と合調回路との間のインビー ダンスは出來る丈け高くする必要がある。第一圖はての場合の結線を示したるるのである。圖に 示すが如く、饋電線に加へられる電壓恰合調回路の電流と、二つの並列回路のインビーダンスに

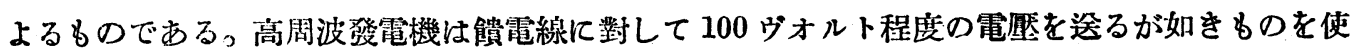
用する。而してての高周波電知も配電變壓器によつて、電燈用の電力と同じく遞降されるもので ある。今瞶電線つ一次電塺を 2300 ヴオルト二次を 115 ヴオルトとする時は高周波の 100 ヴオ ルトは二次側て於ては 5 ヴオルトとなり、其の影響は小なるるのである。

命調橙電器は命調狀態となり、乙の制御電流が流れる時に繼電器の發電子を引んて働かすもの 


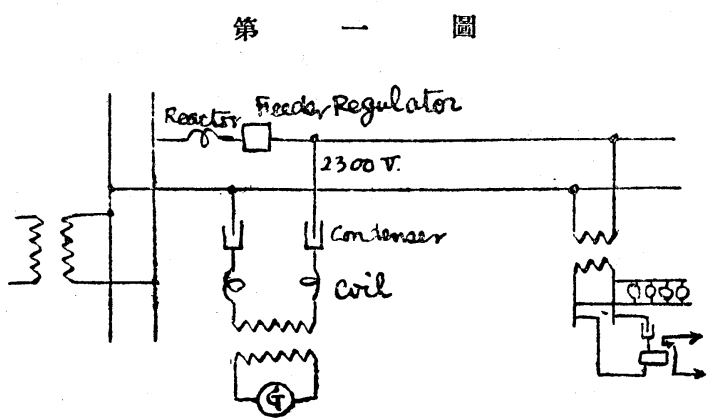

でこの繼電器の大略の棈造は第二圖に 示すが如きものである。繼電器は簡單 なるU 字形の電磁石より爲り、てれに よつて、引き着けられる發電子は接觸 開閉器に結ばれている。ての繼電器の 拦線電磁石を作る目的及び特殊の周 波數のものに對してのみ働く、合調回 路に對して必要なるインダクタンスと なるものである。故に使用周波數の場 合に回路のリアクタンスが賽際に於 て、零である時、制御回路の電流は有效レヂスタンスによつて制限されるのである。ての抵抗は、 使用電力に加へられたる、制御電力より充分なるェネルギーを取る爲に出承る丈け低く取る必要 がある。ての鹞に繼電器の設計に對して各種の注意が必要である。

㺦電器は出柬る丈り損失の少ない事が必要である。てれは 500 サイクルに對して、其の損失小 なる鐵心を使用し且つ、適當なる空氣間隙、嬑線方法。及び蓄電器を借ふる必要がある。合調回路の

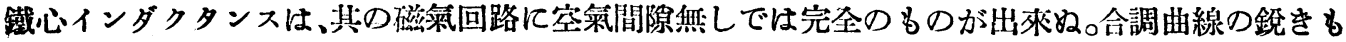
のを求むれば其の回路を流るる電流が電望に對して 90 度に近き相差を有する事が必要である。

第 二 圆

第 三罟
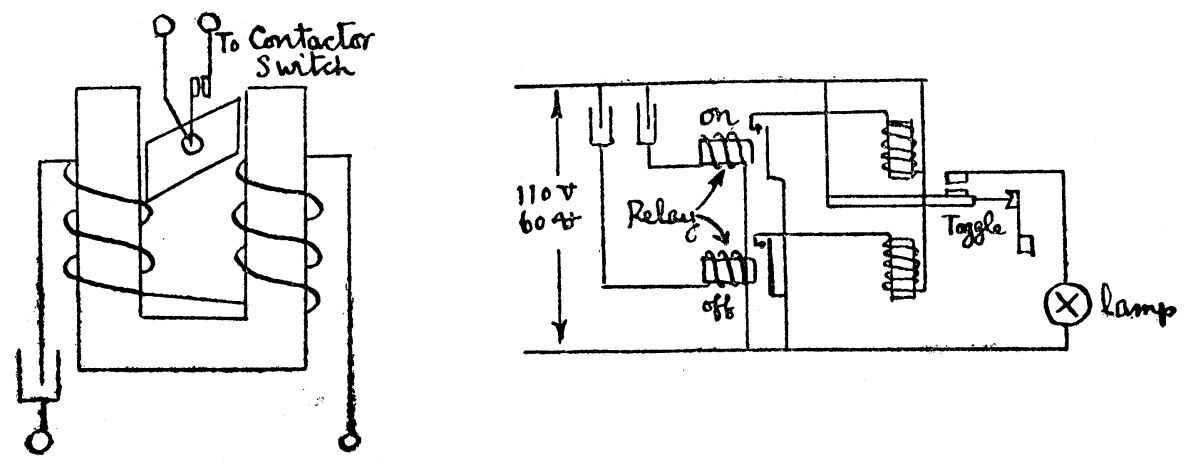

ての繼電器は蓄電器によつて電力回路に接續されている。ての蓄電器は又使用電力のものが繼 電器の回路に流入するを防ぐものでする。

故に繼電器は常に電力回路に接縜されているが其の回路を流れる電流々小なるものでての電流 は其の繼電器が働くより遙に少量のものであるが進電流であるから回路の力率補正に使用される。 全體の制御接䋶は第三圖に示した如きものである。てれは全體適當の箱に收められて居り電燈 の回路を開閉する接觸開閉器は Toggle 型のものである。

合調制御裝置は街路照明回路の制御の外に油入遮斷器、又は種々の自働制御裝置に使用される ものである。(門倉)

24. 電化されたる料理及びパン燒を

\section{Electrically Heated Commercial Cooking and Baking Equipment.}

By. R. H. Macgillwray.

Electric Journal, Dec. 1926. 
電化すべき、大なる一つの方面はホテル、料理店及び、バン燒工場である。是等のるのに對す る電熱應用は最近に於て䉆されたもので其の結果は皆良好である。數年前迄は電熱を是等のもの て應用したるのは極めて少なかつたが、今日では其つ數は非常に增加して柬た電熱を使用したる ものは其の製品の優良及び經濟上の利益を得ているのである。

米國に於ては 40000 軒の料理店があつてててに於ては每日、35000000の食事を供給して居り カフェーテリヤも非常に多!、米國全體で 38600 軒で每日、35000000 の食事を供給している。

バン燒工場に就て見るに、米國に於ては小賣のパン店が 26000 軒で卸し店は 2500 軒である。 其の各は 10000 弗以上の設備を有するものである。

電熱を利用したものは他の石炭等の燃料に比して種々なる利點を有するものであるが而し、其 の費用に就ては常に論議せらるる所である。而してての料金て對しても最近には非常に適當した ものとなつて來た。

電熱を使用する事の利益を揭ぐれば次を゙如を事である。

電熱を利用した料理は最少の時間にて最大の量を仕上げる事が出來而して文其の床面積勞力等 を減少する事が出來る。文燃料の價格の不定による事に無關係であり、其の制御が簡單なる爲に、 是等のものに依る害を受ける事が少なく、火贸の害を受ける事も少ない。

其の上清潔なるが故に、其の能率をよくする事が出棑其の構造上より正確に㗢かしめる事が出 來るのである。

佁、其の運轉費用上飞就ては、電熱 1 キロワット時、2.5 仙、瓦斯 1 千立方吹 1 弗、石炭 1 噸 て就き 15 弗の時に對して比較し得られるのである。而して大なる電熱を利用したる料理所文は バン燒所に就ては上記の料金よりより少なき料金にて電熱を使用しているのである。

パン燒裝置

Sectional type deck 羔に對しては一封度のパンを燒くには約 90 乃至 100 ワット時を要する即 ち、一キロワット時に對して、10 乃至 11 封度のバンを燒く事が出來るのである。镘頭菓子(Postry) 几對しては約ての二倍の電力を必要とするものである。

小なる空で長時間使用した方が大なる㸃で短時間使用した場命より、經濟である。後者は器を 熱する時間が長く要する䉆めである。

使用電力の 50 パーセントが饅頭菓子等を燒く場合に消費されパンを燒く場合には 60 パー七 ントが利用される。てれは窯を熱する爲に使用される割合を示したものである。

多くの電熱羔は冷却狀態より使用狀態迄加熱するに約 1 時間乃至1.5 時間を要するものである。

一般料理に就て

全部電化されたる、レストラントメはホテルに於ては、一つの料理を仕上ぐるには400 乃至 500 ワット時を要するものである。ての數字は簡單なる料理を作るものに對しては過大である。 是等のものに對しては第一表に示した如くになる。

\begin{tabular}{|c|c|c|c|c|c|c|c|}
\hline & & \multicolumn{2}{|r|}{ 第 } & \multicolumn{2}{|c|}{ 表 } & \multirow[b]{2}{*}{$\begin{array}{c}\text { 電力料金 } \\
1 \text { KWH. }\end{array}$} & \multirow[b]{2}{*}{$\begin{array}{l}\text { 一料理に使 } \\
\text { 用するWatt. }\end{array}$} \\
\hline & & & $\begin{array}{l}\text { 需 要 } \\
\mathrm{KW}\end{array}$ & $\begin{array}{l}\text { 一ร月使用 } \\
\text { KW.H. }\end{array}$ & 一ヶ月間 & & \\
\hline 病 & 院 & 47 & 28.2 & 6000 & 31500 & 1.5 & 190 \\
\hline 講 習 & 所 & 27.5 & 13.7 & 14900 & 4500 & 3.19 & 328 \\
\hline レスト & ラン & 98 & 65 & 35680 & 60000 & 1.42 & 597 \\
\hline 間 & 校 & 139 & 42 & 8040 & 34650 & 2.84 & 232 \\
\hline ホ テ & $ル$ & 110 & .. & 13168 & 30000 & 1.5 & 438 \\
\hline
\end{tabular}


$\begin{array}{lllllll}ク \text { ラ ブ } & 186.2 & 143 & 42000 & 75000 & 1.43 & 560\end{array}$

パン燒をの賽際の試驗を、ホテルのレンヂで行つた結果、電熱を使用した昜合は、燃料を使用 したものより被縮を減少する事が出來た。其の數字的結果は瓦斯入は石吙を使用したるのに比し て電熱は 10 乃至 20 パーセントの被縮を減少する事が出來たのである。

瓦斯及び電熱を使用せるべカリーに於て試驗した結果、饅頭菓子に就ては電熱の方が六分の五、 パンに就ては三分の一刎縮が少なく、一ケ月を通して 656 封度約 60 弗の經湾となるのである。 义、電熱にて料理したものは瓦斯义は石炭を使用したものに比して、長時間に其の新鮮味を保つ 事が出來るのである。(門倉) 